\title{
Age-Dependent Availability and Functionality of Bone Marrow Stem Cells in an Experimental Model of Acute and Chronic Myocardial Infarction
}

\author{
Ana Ayala-Lugo, ${ }^{*}$ Angela M. V. Tavares, $\dagger^{* *}$ Ana H. R. Paz,* Ana Alegretti,* \\ Ludmila Miquelito,* Hugo Bock,\# Roberto Giugliani, $\ddagger \S \# \S \S$ Nadine Clausell, $\dagger$ I†† \\ Elizabeth Cirne-Lima,**t and Luis E. Rohde $+\mathscr{T}+\dagger$
}

*Embriology and Cell Differentiation Laboratory, Hospital de Clínicas de Porto Alegre, Porto Alegre, Brazil †Cardiovascular Research Laboratory, Hospital de Clínicas de Porto Alegre, Porto Alegre, Brazil $\ddagger$ Medical Genetics Service, Hospital de Clínicas de Porto Alegre, Porto Alegre, Brazil §Post-Graduate Program of Genetics and Molecular Biology, Federal University of Rio Grande do Sul (UFRGS), Porto Alegre, Brazil

IPPost-Graduate Program of Cardiology and Cardiovascular Sciences, Federal University of Rio Grande do Sul (UFRGS), Porto Alegre, Brazil

\#Post-Graduate Program of Biologic Sciences: Biochemistry, Federal University of Rio Grande do Sul (UFRGS), Porto Alegre, Brazil

**Cardiovascular Physiology Laboratory, Physiology Departament, Federal University of Rio Grande do Sul (UFRGS), Porto Alegre, Brazil

$\dagger \dagger$ Medical School, Federal University of Rio Grande do Sul (UFRGS), Porto Alegre, Brazil $\$ \neq$ Veterinary School, Federal University of Rio Grande do Sul (UFRGS), Porto Alegre, Brazil $\S \S$ Biosciences Institute, Federal University of Rio Grande do Sul (UFRGS), Porto Alegre, Brazil

\begin{abstract}
The aim of this study was to investigate the effect of aging and timing of left ventricular ischemic injury on the availability and functionality of stem cells. We studied young and aged male inbred Lewis rats that were used as donors of bone marrow mononuclear cells (BM-MNCs), divided in four experimental groups: controls, sham operated, $48 \mathrm{~h}$ post-myocardial infarction (MI), and 28 days post-MI. In vitro studies included flow cytometry analysis, hematopoietic colony-forming capacity, and invasion assays of migration capacity. BM-MNCs from these groups were transplanted in female rats after MI induction. Late engraftment was evaluated by real-time PCR of the SRY chromosome. Percentage of CD34 $/$ CD $45^{\text {tow }}$ cells was similar among different experimental groups in young rats, but was significantly higher in aged animals $(p<0.001)$, particularly 28 days post-MI. $\mathrm{KDR}^{+} / \mathrm{CD} 34^{+}$cells were increased $48 \mathrm{~h}$ after $\mathrm{MI}$ and decreased 28 days post-MI in young animals, while they were profoundly reduced in the aged group $(p<0.001)$. Triple staining for $\mathrm{CD} 44^{+} / \mathrm{CD} 29^{+} / \mathrm{CD} 71^{+}$cells was similar in different groups of aged rats, but we observed an intense increase $48 \mathrm{~h}$ post-MI in young animals. Colony-forming units and cytokine-induced migration were significantly attenuated 28 days after the MI. Late engraftment in infarcted transplanted female hearts was present, but considerably heterogeneous. Finally, recovery of left ventricular systolic function in transplanted female recipients was significantly influenced by donors' BM-MNCs groups $(p<0.01)$. We have demonstrated that aging and timing of myocardial injury are factors that may act synergistically in determining stem cell availability and function. Such interaction should be considered when planning new cell therapy strategies for acute and chronic ischemic heart disease in the clinical arena.
\end{abstract}

Key words: Cell therapy; Myocardial infarction (MI); Aging

\section{INTRODUCTION}

Cell therapy has emerged in the last decade as a potentially ground-breaking strategy to treat cardiovascular disease (24). In 2001, Orlic et al. published two land- mark studies showing that locally delivered (20) and cytokine-mediated translocation of bone marrow cells (21) could generate de novo myocardium. The newly formed tissue occupied approximately $68 \%$ of the infarcted segment and substantially decreased mortality rates. These

Received May 2, 2009; final acceptance June 15, 2010. Online prepub date: August 18, 2010.

Address correspondence to Luis E. Rohde, M.D., Heart Failure and Transplant Unit and the Cardiovascular Research Laboratory, Hospital de Clínicas de Porto Alegre, Rua Ramiro Barcelos 2350, Sala 2061, Porto Alegre, RS, Brazil 90035-003. Phone/Fax: 55 51 21018344; E-mail: lerohde@terra.com.br 
remarkable results were partially replicated by several groups of investigators using different progenitor cell types in distinct experimental models of heart dysfunction $(4,7,12,14,15,17,27,30,32,33,37)$. Data from small clinical studies that used primarily intracoronary bone marrow mononuclear cells (BM-MNCs) after an acute myocardial infarction, however, were not as impressive. Overall, increments in left ventricular ejection fraction (LVEF) attributed to stem cell therapy were modest or nonsignificant $(1,13,16,28)$. Indeed, Lunde et al. found a marginal decrease in LVEF assessed by magnetic resonance imaging 6 months after cell transplantation in a small randomized trial (16). Reasons for these discrepancies and disappointing results are unclear and certainly complex, but might be related to stem cell type, abundance, quality, and function, as well as timing of the intervention.

Recently, a group of investigators published intriguing findings suggesting that BM-MNCs from patients with chronic ischemic cardiomyopathy are profoundly limited in their ability to migrate and form colonies. This impaired cellular functionality was also associated to reduced neovascularization capacity in vivo (9). Factors responsible for this functional impairment are uncertain, but aging, cardiovascular atherosclerotic risk factors and left ventricular pump dysfunction may be intrinsically involved. Although stem cell characterization implies in extensive and even indefinite self-renewal capacity, there is recent evidence suggesting that functional properties of hematopoietic stem cells may in fact profoundly altered with aging $(2,8,18)$. Importantly, taken together these findings may limit the therapeutic potential of most cell therapy strategies in the cardiovascular setting.

In the present protocol, we sought to investigate the role of aging and timing of left ventricular damage on the abundance and functionality of stem cells in an experimental model of acute and chronic myocardial infarction, using young and aged male Lewis rats as BMMNCs donors.

\section{MATERIALS AND METHODS}

\section{Animals}

Male and female inbred Lewis rats were obtained from CEMIB-UNICAMP (Campinas, Brazil) and used as donors (males) and recipients (females) of BMMNCs. All procedures were approved by the Ethics Committee of Hospital de Clinicas de Porto Alegre (HCPA), and performed according to the principles of the Brazilian College on Animal Experimentation (www. cobea.org.br), the Council for International Organizations of Medical Science, and the US National Institutes of Health. A subgroup of male Lewis rats was aged for
12 months at the animals' facilities of HCPA, given food and water ad libitum in day and night cycles of $12 \mathrm{~h}$.

\section{BM-MNC Donors}

Young (8-10 weeks old) and aged (12 months old) male inbred Lewis rats were used as donors for BMMNCs analysis, divided in several experimental groups (6-8 animals/group): 1) control animals, 2) sham-operated animals, 3) acute myocardial infarction (MI) animals, and 4) chronic ischemic heart failure. In the acute MI animals, BM-MNCs were collected $48 \mathrm{~h}$ after left anterior descending artery ligation, while in the chronic ischemic heart failure animals BM-MNCs were harvested 28 days after MI induction.<

\section{BM-MNC Recipients}

Female inbred Lewis rats (8-10 weeks old) were transplanted with BM-MNCs derived from the 8 experimental groups described above (4 groups of young rats and 4 groups of aged rats), immediately after induction of an acute MI.

\section{Myocardial Infarction Model}

MI was induced according to a procedure previously described in the literature (23) and adapted in our laboratory. In brief, animals were placed in dorsal decubitus and anesthetized with xilazine $(0.67 \mathrm{mg} / \mathrm{kg})$ and ketamine $(0.33 \mathrm{mg} / \mathrm{kg})$ administered intraperitoneally. Following orotracheal intubation, animals underwent mechanical ventilation (60 movements/min and a tidal volume of $1.5 \mathrm{ml}$ ) with a Harvard ventilator (Model 683, Harvard Medical, MA). A surgical incision was performed in the skin along the left sternal margin, divulsion of pectoralis and transverse muscles was made, thoracotomy was performed at the third intercostal space, without exteriorization of the heart. The left anterior descending coronary artery (LAD) was identified and ligated with a 6-0 mononylon suture, between the left atrial appendage margin and the pulmonary artery. Next, the thoracic cavity was closed with a 5-0 mononylon suture, muscles were repositioned, and the skin sutured. All animals received analgesia after surgery (dipirone $0.1 \mathrm{ml}$, IM). Sham-operated rats underwent the same procedure, except for LAD ligation.

\section{Isolation of BM-MNCs}

Donors (male Lewis rats) were individually killed and both femurs and tibias were removed in sterile conditions. All connective tissue was removed and bones were placed in culture medium [Iscove's modified Dulbecco's medium (IMDM, Gibco) with 10\% fetal bovine serum (Gibco), $1 \%$ penicillin $(10,000 \mathrm{U} / \mathrm{ml})$, and $1 \%$ streptomycin $(10,000 \mu \mathrm{g} / \mathrm{ml}$, Gibco)]. Proximal and distal margins of the tibia and femur were then clipped to 
expose the marrow; bone marrow cells were recovered by the "flushing procedure" using a 22-gauge needle and a 5-cc syringe filled with culture medium. Cell suspension was washed twice and transferred to a sterile tube. BM-MNCs were isolated by centrifugation through a Ficoll-plaque Plus (Amersham Biosciences) density gradient. Briefly, cells suspension was loaded on a 50\% Ficoll gradient, according to the manufacturer's indications, and centrifuged at $1500 \mathrm{rpm}$ for $15 \mathrm{~min}$. Fat and serum layers were discarded, and the band of low-density white cells was collected, washed twice, and studied for cell viability with trypan blue. These BM-MNCs were used for the in vitro and in vivo studies.

\section{In Vitro Studies}

Flow Cytometry Analysis. Approximately $1 \times 10^{6}$ BM-MNCs were prepared. They were place in sterile tubes and washed two times by centrifugation at 2000 $\mathrm{rpm}$ for $5 \mathrm{~min}$ at $4^{\circ} \mathrm{C}$. BM-MNCs were then resuspended in $200 \mu \mathrm{l}$ of PBS and incubated for $20 \mathrm{~min}$ at $4^{\circ} \mathrm{C}$ with anti-CD45/FITC (CALTAG lab) and anti-CD34/PE (Santa Cruz Biotechnologies); anti-KDR (Abcam) and anti-CD34/PE (Santa Cruz Biotechnologies). We also performed triple staining for anti-CD44/FITC (Abcam), anti-CD71/PE (AbD serotec), and anti-CD29/PECy5 (BioLegend). All assays were conducted using concentration of antibodies that were recommended by manufacturers. Phycoerythrin-PE and FITC mouse anti-rat $\mathrm{IgG1}, \mathrm{IgG} 2 \mathrm{a}$, and $\mathrm{IgM}$ were used as isotype controls. After incubation of antibodies, lysis solution $(1 \mathrm{ml})$ was added for $15 \mathrm{~min}$ to hemolize erythrocytes; then $1 \mathrm{ml}$ of PBS was added for $15 \mathrm{~min}$ to stop the hemolytic treatment. Cells were collected and washed with PBS by centrifugation and $500 \mu \mathrm{l}$ of PBS was added to prepare the cell suspension. Analysis was carried out with the BD FACS-Calibur flow cytometry system with the onelaser system that is capable of detecting three fluorochromes excited by the 488-nm laser in a multiparameter manner. The samples were read in the cellquest and PAINT-A-GATE softwares.

Hematopoietic Colony-Forming Unit. BM-MNCs were seeded in methylcellulose (Methocult GF R3774, Stem Cell Technologies, Vancouver) containing Iscove's medium, fetal bovine serum, bovine serum albumin, mercaptoethanol, and recombinant cytokines (stem cell factor, granulocytic-macrophage colony stimulating factor, and interleukin-3). Cells were plated in triplicate at $1 \times 10^{4}$ cells per plate and cultures were incubated at $37^{\circ} \mathrm{C}$ and $5 \% \mathrm{CO}_{2}$. After 10 days of incubation, cultures were removed and the plates were studied under phasecontrast microscopy. Granulocyte-macrophage, isolated granulocyte, and total colony-forming units were counted (Fig. 1). Colony forming units were counted when-

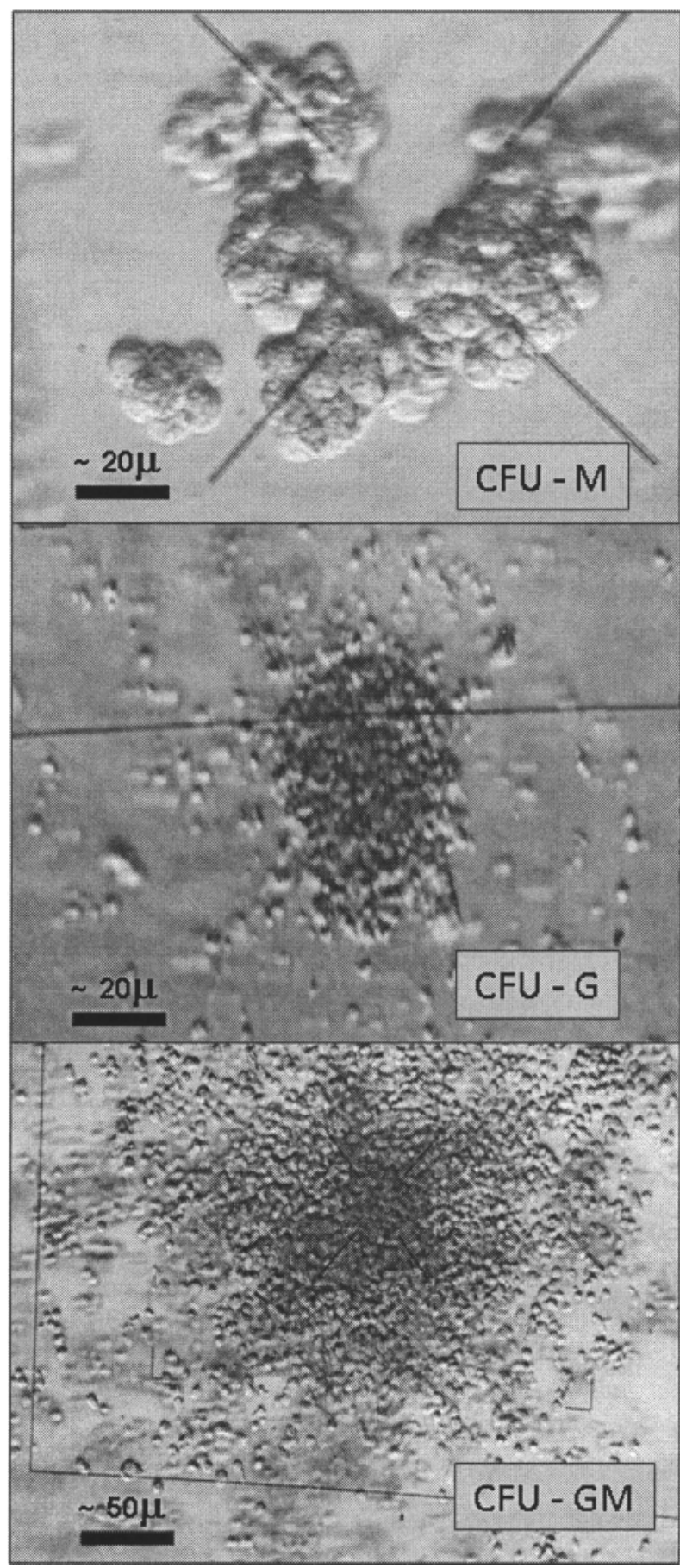

Figure 1. Representative examples of different types of colony-forming units.

ever aggregation was greater than 50 cells. Counting was performed by a technician that was blinded for the assignment of experimental groups.

Migratory Capacity (Invasion Assay). Invasion assay assessing the ability of cells to invade a synthetic basement membrane was performed in invasion chambers 
with $8 \mu \mathrm{m}$ pore size PET membrane (cell culture insert, BD Bioscience) separating the upper and lower chambers. The top surface of the membrane was coated with Matrigel matrix [BD Matrigel ${ }^{\mathrm{TM}}$ Basement Membrane Matrix High Concentration (HC) Phenol Red Free]. The chamber was placed in a 24-well culture dish containing $500 \mu \mathrm{l}$ of culture medium, $50 \mathrm{ng} / \mathrm{ml}$ of vascular endothelial growth factor (VEGF, Biosource International), and $100 \mathrm{ng} / \mathrm{ml}$ of stromal cell-derived factor 1 (SDF-1, Biosource International). After $24 \mathrm{~h}$ of incubation at $37^{\circ} \mathrm{C}$ and $5 \% \mathrm{CO}_{2}$, the noninvading cells on the top surface of the filter membrane were removed with a cotton swab and the transmigrated cells found on the bottom surface were counted, as previously described (9). Counting was performed by a technician that was blinded for the assignment of experimental groups. The number of transmigrated cells was counted under a microscope at $400 \times$ magnification and the mean number of cells per field in 10 random fields was recorded and used for statistical analysis.

\section{In Vivo Studies}

Cell Transplantation Procedure. Recipients (female Lewis rats) were infarcted as described above. Immediately after operation, $1 \times 10^{6} \mathrm{BM}-\mathrm{MNCs}$ from each experimental group were resuspended in $70 \mu \mathrm{l}$ of culture medium without serum and were injected at 5-6 points in the border zone of the infarcted area. For the cell transplant procedure, each male donor rat had one or two reciprocating female recipients. All female recipients were euthanized 28 day after the MI to search for the presence $\mathrm{Y}$ chromosome in the transplanted heart.

SRY Chromosome Analysis by Real-Time PCR. Genomic DNA was extracted using the Purelink genomic DNA kit (Invitrogen) and quantified with Quant-it DSDNA assay kit. Triplicate real-time PCR reactions were performed using $20 \mathrm{ng}$ of each genomic DNA. Real-time PCR reactions were performed using the ABI PRISM 7500 PCR System (Applied Biosystems), the TaqMan Gene Expression Assay-SRY (Applied Biosystems), and the Rat GAPD (GAPDH), as an endogenous control (Endogenous Control VIC/MGB Probem primer Limite, Applied Biosystems) to normalize the amount of DNA. The cycling conditions $(n=50)$ were $2 \mathrm{~min}$ at $50^{\circ} \mathrm{C}, 10 \mathrm{~min}$ at $95^{\circ} \mathrm{C}$ for polymerase activation and denaturation, $15 \mathrm{~s}$ at $95^{\circ} \mathrm{C}$ for annealing, and $1 \mathrm{~min}$ at $60^{\circ} \mathrm{C}$ for extension. For relative quantification of SRY amplification, specific calibration (from young control animals) was used for each segment of the ventricle analyzed (on an animal per animal comparison).

Echocardiography. Donor animals underwent twodimensional Doppler echocardiography after the surgical procedures to attest that MI was induced and sham pro- cedures did not affect left ventricular (LV) systolic function. Echocardiographic studies were performed under light intraperitoneal anesthesia and spontaneous respiration. Fundamental and harmonic cardiac imaging was obtained by an ultrasonographer experienced in rodent imaging, using an EnVisor HD System (Philips Medical, Andover, MA) and a $12-13 \mathrm{MHz}$ linear transducer. Animals were placed in the left lateral decubitus position $\left(45^{\circ}\right)$ in a warm environment to obtain cardiac images. M-mode, two-dimensional, and Doppler images from the parasternal and apical views were obtained and recorded on digital format for off-line measurements. Echocardiography-derived parameters used for the current analysis included LV fractional area change and MI size, using a previously validated protocol (19). LV systolic function was estimated by calculating the fractional area chance $(\mathrm{FAC})$, calculated as: $\mathrm{FAC}=$ (end-diastolic transverse area - end-systolic transverse area/end-diastolic transverse area) $\times 100$. The final FAC is reported as a percentage and represents the mean from three transverse planes (basal, medial, and apical). In addition, on each echocardiographic transverse plane the arc corresponding to the segments with infarction (AI) - representing segments showing hypokinesis, akinesis, and/or dyskinesis - and to the total perimeter of the endocardial border (EP) was measured at end-diastole. Infarction size (IS) was estimated as previously described as: IS $(\%)=(\mathrm{AI} / \mathrm{EP}) \times 100$. The final value of myocardial infarction size for each animal is reported as the mean IS obtained from the same transverse planes. As previously reported (19), there is an excellent agreement between echocardiography and histology for infarct size assessment in the rodent experimental model ( $r=0.88$ between echo and histology findings). After undergoing echocardiography, animals were killed and underwent thoracotomy for heart and lung removal.

\section{Statistical Analysis}

Continuous variables with normal distribution were expressed as average $\pm \mathrm{SD}$ and compared using Student's $t$-test or variance analysis (ANOVA). Post hoc analysis using the Tukey test was applied whenever appropriate. General linear models (GLM) were used to evaluate differences between young and aged animals and to evaluate the potential interaction between age and timing of MI. Categorical variables were expressed as frequencies and percentages. For comparisons between different groups, the chi-square test or Fisher's exact test was used. A multivariate model was also created to assess independent predictors for the migration analysis and the colony-forming unit assay. A bi-caudal value of $p<0.05$ was considered statistically significant. Analyses were performed using SAS for Windows statistical package (version 8.0). 


\section{RESULTS}

\section{Donors (Male Inbred Lewis Rats)}

Perioperative surgical mortality for MI induction was approximately $40 \%$, mostly related to anesthesia hypersensitivity and infarct-related events. As expected, left ventricular systolic fractional area change was substantially reduced in infarcted animals when compared to control and sham-operated rats $[0.41 \pm 0.10 \%$ for the 28 days post-MI group vs. $0.49 \pm 0.13 \%$ for the $48 \mathrm{~h}$ postMI group vs. $0.64 \pm 0.08 \%$ for the sham-operated group vs. $0.69 \pm 0.03 \%$ for the control group; $p<0.0001$, pos hoc analysis showing significant differences between infarcted animals versus non-infarcted animals (shams and controls)]. No segmental abnormalities were identified in sham-operated and control animals, while the average infarct size from the remaining infarcted animals was $50 \pm$ $14.9 \%$, representing a large amount of damaged myocardium.

\section{Flow Cytometry Analysis}

Hematopoietic Stem Cell Markers. To investigate whether the number of hematopoietic stem/progenitor cells is reduced in BM-MNCs of young and aged rats with early and late MI, we determined the percentage of stem progenitor cells characterized by CD34 and CD45 expression. Overall, $\mathrm{CD} 34^{+} / \mathrm{CD} 45^{\text {tow }}$ cells were marginally increased after 28 days post-MI. The percentage of $\mathrm{CD} 34^{+} / \mathrm{CD} 45^{\text {How }}$ BM-MNCs was similar among different experimental groups in young rats, but in aged rats the number of $\mathrm{CD} 34^{+} / \mathrm{CD} 45^{\text {Hlow }}$ was significantly higher $(p<0.001)$, particularly 28 days after the MI (Fig. 2). We observed a significant interaction between age and experimental groups in this analysis $(p<0.001$ for GLM interaction term).

Endothelial Progenitor Cell (EPC) Markers. The percentage of endothelial progenitors in the BM-MNCs was determined by the expression of KDR and CD34 (Fig. 3). Overall, EPCs were significantly increased after an acute MI when compared with control and sham animals; however, the percentage of $\mathrm{KDR}^{+} / \mathrm{CD} 34^{+}$cells was substantially reduced 28 days after the MI. In young animals, $\mathrm{KDR}^{+} / \mathrm{CD} 4^{+}$were increased $48 \mathrm{~h}$ after the $\mathrm{MI}$ and decreased 28 days after the MI, when compared to control and sham-operated animals. Notably, EPCs were profoundly reduced in the aged group $(p<0.001)$. Aged animals had a 7.8 -fold reduction in $\mathrm{KDR}^{+} / \mathrm{CD} 34^{+}$cells $48 \mathrm{~h}$ after the MI and a sevenfold reduction 28 days after the MI (Fig. 3B). For this analysis, we observed a tendency of interaction between age and experimental groups ( $p=0.06$ for GLM interaction term).

Mesenchymal Stem Cells Marker. Although there is not a consensual set of markers for mesenchymal stem cells detection in vivo or in the bone marrow, for the purpose of this study we used the concomitant expression of CD44, CD29, and CD71 as potential indicators of this lineage. Individually, expression of these markers was age-dependent and significantly diverse according to experimental groups (Fig. 4). For instance, CD71 ${ }^{+}$ cells were more than threefold increased $48 \mathrm{~h}$ post-MI when compared to sham-operated rats in young animals, while in aged animals they were increased only 28 days post-MI. Triple staining $\left(\mathrm{CD} 44^{+} / \mathrm{CD} 29^{+} / \mathrm{CD} 71^{+}\right.$cells) (Fig. 4C) was similar in aged rats irrespective of the experimental groups, but we observed an intense increase of $\mathrm{CD} 44^{+} / \mathrm{CD} 29^{+} / \mathrm{CD} 71^{+}$cells $48 \mathrm{~h}$ post-MI in young animals $(p<0.001$, post hoc analysis depicting significant differences to all other groups) (Fig. 4C). For triple staining, we observed a significant interaction between age and experimental groups $(p<0.001$ for GLM interaction term).

\section{Colony-Forming Units and Migration Assay}

The functional capacity of progenitor cells in the bone marrow aspirates was determined by measuring the colony-forming activity. The same profile of colonyforming capability was observed in young and aged animals. Overall, we observed a significant increase in the absolute number of colonies after the sham procedure and $48 \mathrm{~h}$ post-MI. This amplified functionality was completely abolished after 28 days post-MI (Fig. 5A). The same findings were observed in analysis stratified for the granulocytic-monocytic- and monocytic-forming units. A similar profile of migration response to SDF- $1 \alpha$ and VEGF was observed in young and aged animals. However, migration was also significantly attenuated after 28 days post-MI (Fig. 5B). No interaction between age and experimental groups was identified for migration and colony-forming capacity.

No significant association was observed between colony-forming and migration capacity (correlation coefficient $<0.10, p=0.76$ ). In a multivariate model adjusted for age, percentage of $\mathrm{KDR}^{+} / \mathrm{CD} 34^{+}$cells, percentage of CD $34^{+} / \mathrm{CD} 5^{\text {How }}$ cells and experimental groups, migration capacity was independently associated only to timing of the MI, indicating a substantial decrease in the ability to migrate in the 28 days post-MI group ( $\beta$ coefficient $-70.8 ; p=0.003$; model $r^{2}=0.33$ ). Conversely, in a multivariate model adjusted for the same variables, granulocytic-monocytic-forming units were independently associate to experimental groups [sham surgery $(p=0.03)$ and $48 \mathrm{~h}$ post-MI $(p=0.01)]$ and aging $(p=$ 0.07 , model $r^{2}=0.46$ ).

\section{SRY Chromosome Analysis (Real-Time PCR)}

For SRY chromosome analysis, 28 days after MI induction and cell transplantation, animals were killed and the left and right ventricles from female recipient hearts 


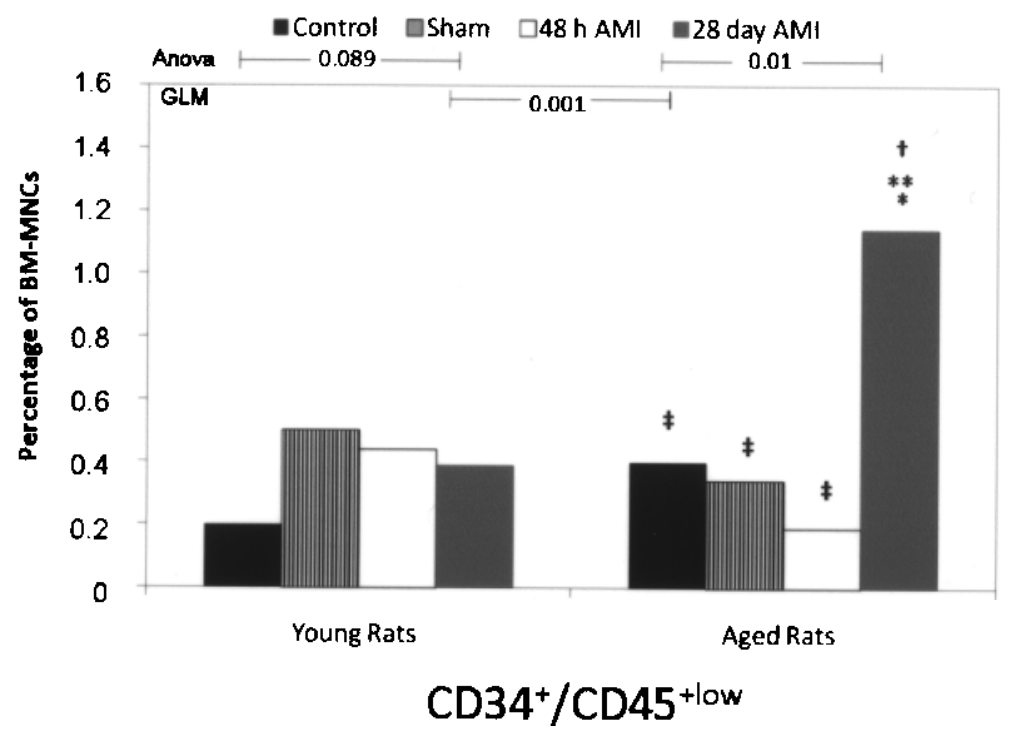

Figure 2. Flow citometry analysis for $\mathrm{CD} 34^{+} / \mathrm{CD} 45^{\text {tow }}$ in young and aged animals according to experimental groups (control, sham, acute MI, and chronic MI). Differences between groups were evaluated by post hoc analysis using the Tukey test: *significant difference between controls and other groups; **significant difference between shams and other groups; † significant difference between acute MI and other groups; $\$$ significant difference between chronic MI and other groups. GLM procedure was applied to identify differences between young and aged animals, as depicted. Interaction term between age and timing of MI was statistically significant $(p<0.001)$.

were separated. Heart tissue from the left ventricle was further divided in basal, medial and apical segments. Amplification of the SRY chromosome was heterogeneous between experimental groups, in different segments of the ventricles of the same animal, and also in triplicates of the same tissue sample. Table 1 describes a qualitative analysis to demonstrate late engraftment of transplanted cells, according to each experimental group of donors. Unfortunately, data from relative quantification of the SRY gene was not reliable to allow statistical analysis, as amplification in individual animals was greatly heterogeneous in triplicates.

\section{Left Ventricular Function (Female Recipients)}

Left ventricular systolic fractional area change in female recipients that were transplanted after induction of an acute MI with BM-MNCs derived from the 8 experimental groups is described in Table 2 . We observed a decrease in left ventricular function recovery in transplanted animals with donor cells from young animals 28 days post-MI (ANOVA $p=0.004$, post hoc difference between donor controls). In addition, left ventricular systolic fractional area change tended to be lower in transplanted animals with donor cells from aged animals ( $p=0.06$ for GLM interaction term between age and experimental groups).

\section{DISCUSSION}

Efficacy of different cell therapies to improve LV systolic function has been limited in most clinical studies $(1,13,16,28)$, despite consistent encouraging results in experimental models of heart injury and regeneration $(7,12,17,30,37)$. In the present protocol, we analyzed the effect and interaction of two central factors that could interfere with the effectiveness of cell therapy in the setting of ischemic heart disease: duration of heart injury and aging. Our findings suggest that there is substantial variability on stem cells' absolute number and functionality related to these factors for all stem cell phenotypes that we evaluated, leading to a diverse capacity to form colonies and migrate. In particular, the interaction of an aged animal with chronic LV injury (28 days post-MI) caused profound changes on these features. Such variability translated in significant changes in left ventricular systolic function assessed by echocardiography in transplanted animals. We believe that such factors should be carefully considered when planning new cell therapy strategies for patients with acute and chronic ischemic heart disease.

Our data suggests that the overall number of hematopoietic stem cells (HSCs) $\left(\mathrm{CD} 34^{+} / \mathrm{CD} 45^{\text {tow }}\right.$ ) was similar in both age strata, but was somewhat increased late after the ischemic injury, particularly in aged animals. In this 
regard, the effect of aging on the absolute number of stem cells is not consensual, but there is solid experimental evidence in murines that HSCs within the bone marrow is increased in concentration and absolute number as the animals ages, paralleled with increased homogeneity of stem cells marker expression. The cause of the increased number of HMCs remains unclear, but a feedback compensatory mechanism could be present in response to a decline in functionality on a per cell basis (2). In fact, several studies have clearly shown that aged
HSCs demonstrate a significant deficit in hematopoietic output when compared to HSC from young mice (18), besides having a higher myeloid progenitor activity. In addition, recent evidences suggest that cell-cell interactions with stroma in the stem cell niche are a central aspect for self-renewal and differentiation, as HSCs are extremely sensitive to these interactions and to secreted factors in this microenvironment. Loss of the osteoblastic niche with aging, associated with a proinflammatory state may participate in this complex interplay that cause
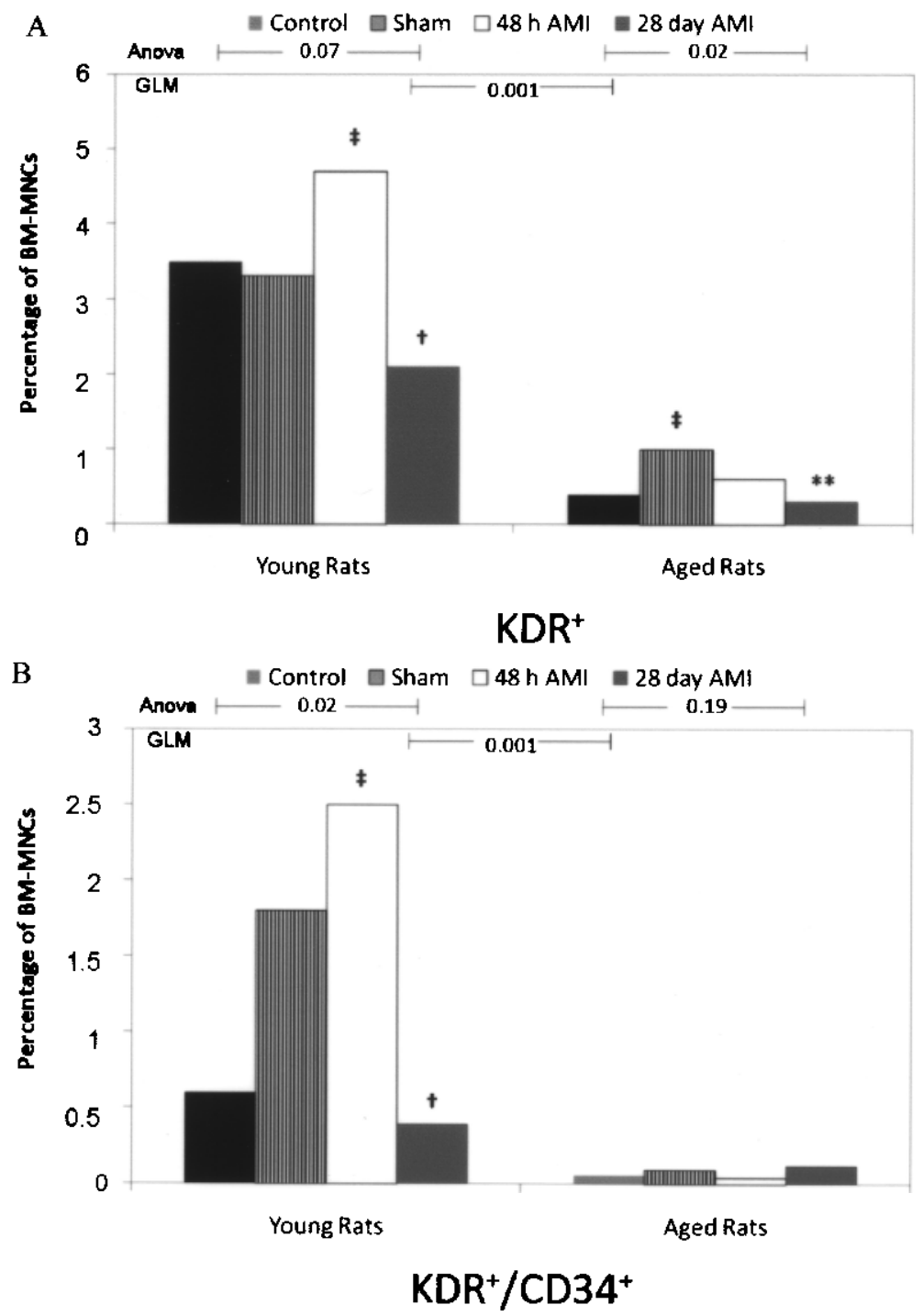

Figure 3. Flow cytometry analysis for total $\mathrm{KDR}^{+}(\mathrm{A})$ and $\mathrm{KDR}^{+} / \mathrm{CD} 34^{+}(\mathrm{B})$ in young and aged animals according to experimental groups (control, sham, acute MI, and chronic MI). Differences between groups were evaluated by post-hoc analysis using the Tukey test: *significant difference between controls and other groups; $* *$ significant difference between shams and other group; $\dagger$ significant difference between acute MI and other groups; $\neq$ significant difference between chronic MI and other groups. GLM procedure was applied to identify differences between young and aged animals, as depicted. Interaction term between age and timing of MI was marginally statistically significant $(p=0.06)$. 

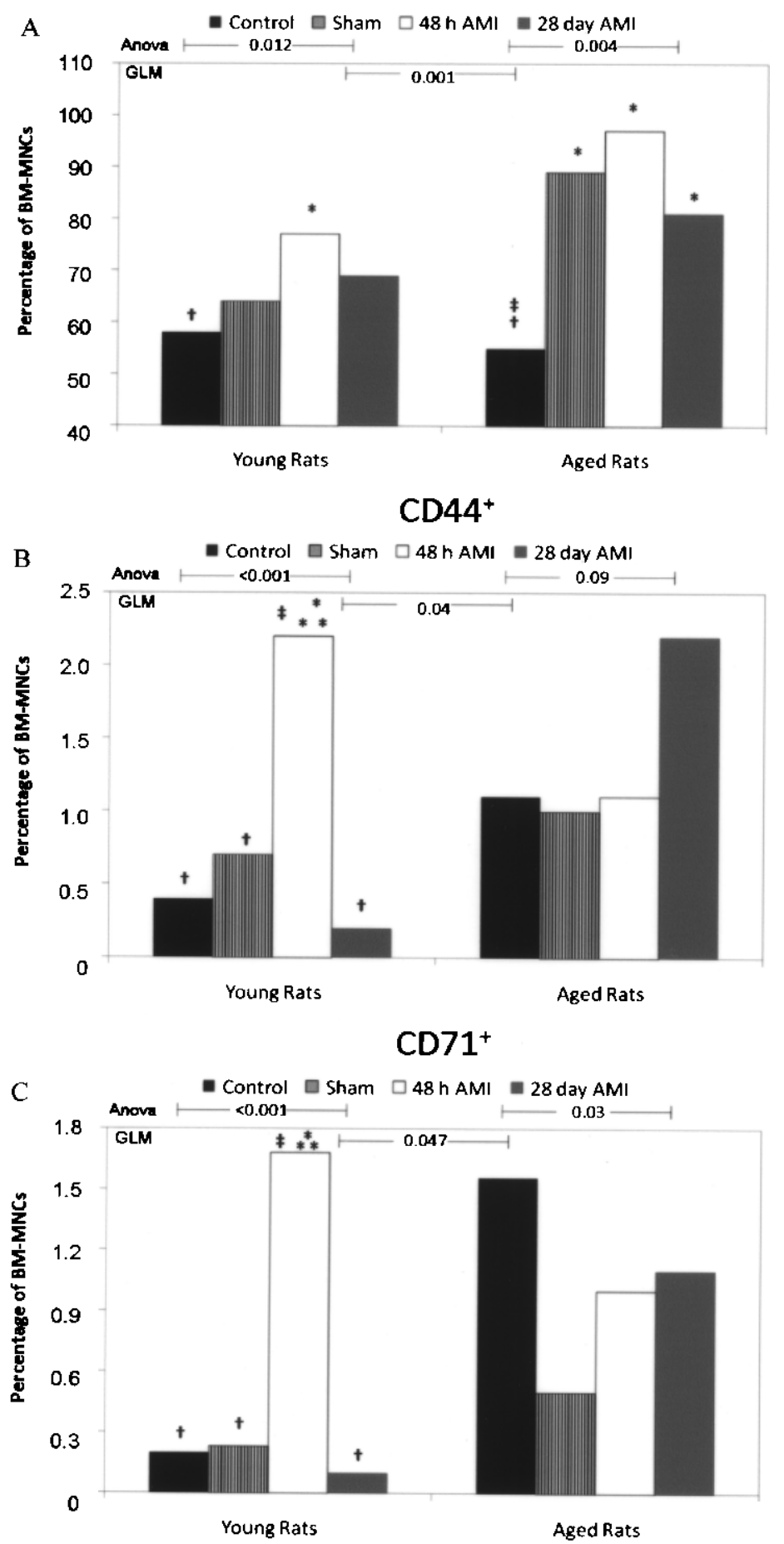

$\mathrm{CD} 44^{+} / \mathrm{CD} 71^{+} / \mathrm{CD} 29^{+}$

Figure 4. Flow cytometry analysis for total CD44 ${ }^{+}(\mathrm{A}), \mathrm{CD} 41^{+}(\mathrm{B})$, and $\mathrm{CD} 44^{+} / \mathrm{CD} 71^{+} / \mathrm{CD} 29^{+}(\mathrm{C})$ in young and aged animals according to experimental groups (control, sham, acute MI, and chronic MI). Differences between groups were evaluated by post hoc analysis using the Tukey test: *significant difference between controls and other groups; **significant difference between shams and other group; †significant difference between acute MI and other groups; $\$$ significant difference between chronic MI and other groups. GLM procedure was applied to identify differences between young and aged animals, as depicted. Interaction term between age and timing of MI was statistically significant $(p<0.001)$. 
A
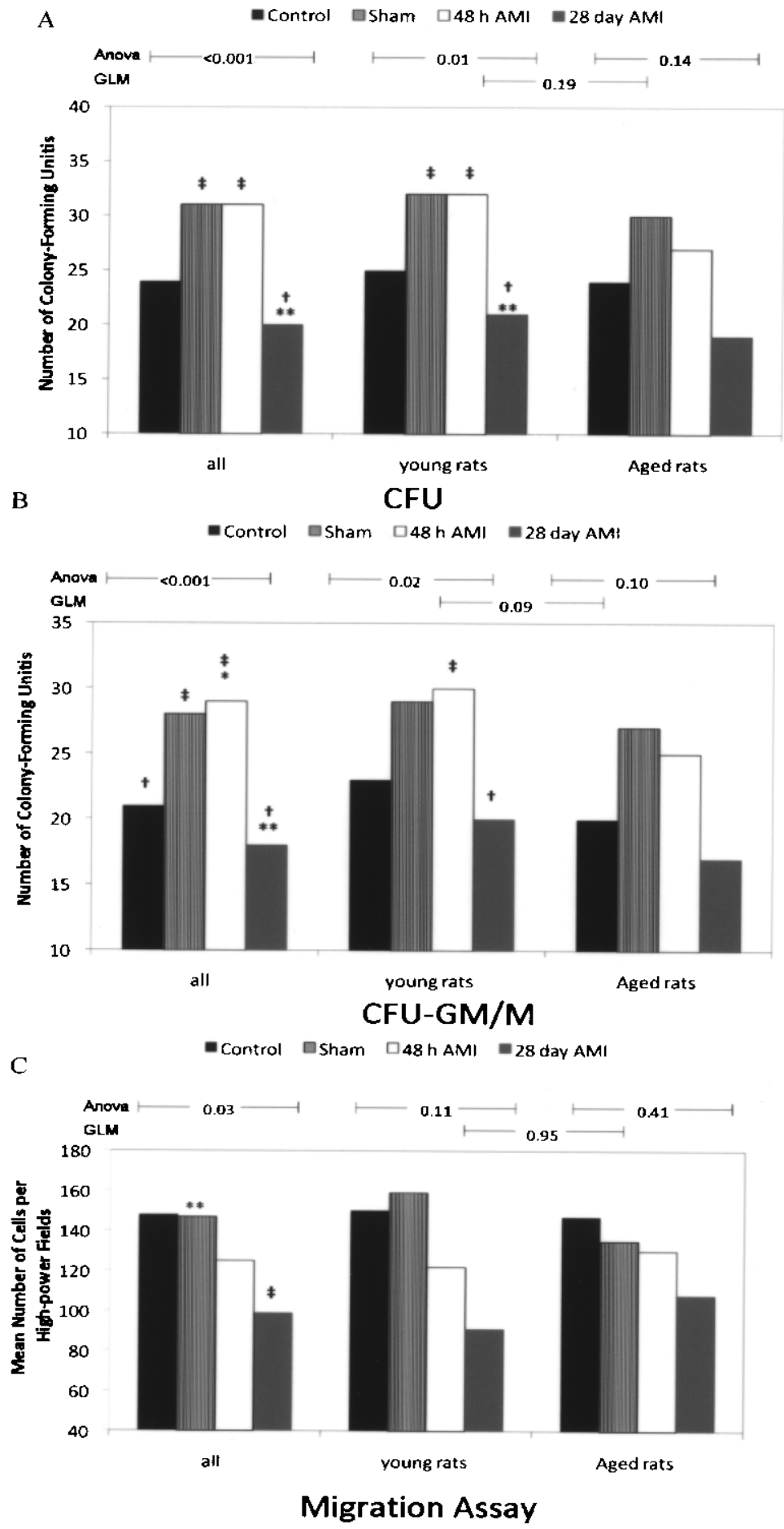

Figure 5. Colony-forming units (A: all types; B: granulocytic-monocytic + granulocytic) and migration capacity $(\mathrm{C})$ in young and aged animals according to experimental groups (control, sham, acute MI, and chronic MI). Differences between groups were evaluated by post hoc analysis using the Tukey test: *significant difference between controls and other groups; **significant difference between shams and other group; †significant difference between acute MI and other groups; $\ddagger$ significant difference between chronic MI and other groups. GLM procedure was applied to identify differences between young and aged animals, as depicted. Interaction term between age and timing of MI was not statistically significant $(p>0.50)$. 
Table 1. SRY Chromosome Analysis by Real-Time PCR

\begin{tabular}{|c|c|c|c|c|}
\hline $\begin{array}{l}\text { Cell Donors } \\
\text { Groups }\end{array}$ & $\begin{array}{c}\text { Right } \\
\text { Ventricle }\end{array}$ & $\begin{array}{c}\text { Left } \\
\text { Ventricle } \\
\text { (Basal Segment) }\end{array}$ & $\begin{array}{c}\text { Left } \\
\text { Ventricle } \\
\text { (Medial Segment) }\end{array}$ & $\begin{array}{c}\text { Left } \\
\text { Ventricle } \\
\text { (Apical Segment) }\end{array}$ \\
\hline \multicolumn{5}{|l|}{ Young animals } \\
\hline Control & $3+/ 3$ & $2+/ 3$ & $3+/ 3$ & $3+/ 3$ \\
\hline Sham-operated & $2+/ 4$ & $4+/ 4$ & $2+/ 4$ & $1+/ 4$ \\
\hline $48 \mathrm{~h}$ post-MI & $3+/ 7$ & $5+/ 6$ & $5+/ 8$ & $6+/ 9$ \\
\hline 28 days post-MI & $1+/ 5$ & $5+/ 6$ & $5+/ 6$ & $4+/ 6$ \\
\hline \multicolumn{5}{|l|}{ Aged animals } \\
\hline Control & $1+/ 3$ & $4+/ 4$ & $3+/ 3$ & $2+/ 3$ \\
\hline Sham-operated & $2+/ 3$ & $1+/ 3$ & $2+/ 3$ & $2+/ 3$ \\
\hline $48 \mathrm{~h}$ post-MI & $2+/ 3$ & $4+/ 5$ & $3+/ 5$ & $3+/ 4$ \\
\hline 28 days post-MI & $1+/ 5$ & $2+/ 5$ & $2+/ 5$ & $4+/ 5$ \\
\hline
\end{tabular}

Values are expressed as number of positive SRY amplification per analyzed animals. Amplification was considered qualitatively positive whenever at least one of the triplicates amplified.

reduced self-renewal and differentiation ability (18). We can speculate that the somewhat unexpected increase in CD $34^{+} / \mathrm{CD} 45^{\text {+low }}$ cells in aged animals late after $\mathrm{MI}$ could be, at least in part, secondary to compensatory mechanisms of feedback associated to impaired autonomous stem cell mobilization from the bone marrow. This absolute increase found in our analysis, however, was accompanied by the "expected" reduced cytokine-induced migration and ability to form granulocytic/monocytic units.

Studies that have evaluated these factors in experimental models of cardiovascular disease are scarce. Heeschen et al. have demonstrated that the number of HSCs remains the same in chronic ischemic heart failure in humans, but the functional capacity of these cells was impaired in a murine model of hind limb ischemia (9). The observed HSCs dysfunction, however, could be secondary to several factors associated to chronic ischemic heart failure, such as risk factors that lead to atherosclerosis, other processes related to coronary artery disease itself, and aging, as heart failure is a disease of the el- derly. In this scenario, our findings suggest that stem cells dysfunction may be to a great extent dependent on the interaction between aging and duration of myocardial injury. For instance, we have demonstrated that $\mathrm{KDR}^{+} / \mathrm{CD} 34^{+}$cells were greatly increased $48 \mathrm{~h}$ after an MI in young rats, an effect that was not observed in aged animals. Previous reports have shown that acute MI is associated with a rapid increased of EPCs in circulation due to a transient mobilization in response to plasma levels of VEGF $(10,11)$. The detailed temporal dynamic of EPCs mobilization after an acute myocardial injury is not clearly defined, but our data suggest that in the setting of chronic heart failure the absolute number of $\mathrm{KDR}^{+}$cells is no longer increased. Moreover, we have also demonstrated that the number of EPCs in the bone marrow was profoundly reduced in the aged group, even after an acute MI. Indeed, in this specific subgroup we have identified a 62 -fold reduction on $\mathrm{KDR}^{+} / \mathrm{CD} 34^{+}$ cells (from $2.5 \pm 1.3 \%$ in young animals $48 \mathrm{~h}$ post-MI to $0.04 \pm 0.03 \%$ in aged animals $48 \mathrm{~h}$ post-MI, $p<0.0001$ in post hoc analysis) (Fig. 4C). Our findings concur with

Table 2. Left Ventricular Systolic Fractional Area Change in Female Rats 28 Days After Cell Transplantation According to Experimental Donor Groups

\begin{tabular}{lccccc}
\hline & $\begin{array}{c}\text { BM-MNCs From } \\
\text { Control } \\
\text { Animals }\end{array}$ & $\begin{array}{c}\text { BM-MNCs From } \\
\text { Sham-Operated } \\
\text { Animals }\end{array}$ & $\begin{array}{c}\text { BM-MNCs From } \\
\text { 48 hostinfarcted } \\
\text { Animals }\end{array}$ & $\begin{array}{c}\text { BM-MNCs From } \\
\text { 28 Days } \\
\text { Postinfarcted } \\
\text { Animals }\end{array}$ & $p$-Value \\
\hline All animals & $0.52 \pm 0.14$ & $0.43 \pm 0.07$ & $0.46 \pm 0.12$ & $0.41 \pm 0.09$ & 0.28 \\
Young animals & $0.62 \pm 0.14$ & $0.48 \pm 0.08$ & $0.47 \pm 0.06$ & $0.37 \pm 0.02$ & $0.004 *$ \\
Aged animals & $0.45 \pm 0.09$ & $0.40 \pm 0.06$ & $0.45 \pm 0.12$ & $0.47 \pm 0.10$ & 0.88 \\
\hline
\end{tabular}

*Post hoc analysis showing difference between BM-MNCs from control versus 28-days postinfarcted animals. GLM interaction term between age and experimental groups: $p=0.06$. 
recent data demonstrating that atherosclerotic risk factors and chronic heart failure are associated to reduced number and function of cultured EPCs, circulating $\mathrm{CD}^{+} 4^{+} / \mathrm{KDR}^{+}$cells and granulocyte macrophage colonyforming units in the bone marrow $(14,36,38)$. A recent report has found similar absolute numbers of EPCs in peripheral blood in older patients with coronary artery disease when compared to younger subjects. These patients, however, apparently did not have significant LV systolic dysfunction (22). This latter finding reinforces the importance of the interaction of aging and presence of myocardial dysfunction as intrinsically dependent factors that might determine peripheral availability of stem/progenitor cells.

The importance of EPCs in the clinical arena have been recently highlighted by data demonstrating that reduced levels of circulating EPCs were an independent predictor of poor prognosis in a heterogeneous group of patients with stable and unstable coronary artery disease (29). Multiple factors determine the number of circulating EPCs, depending on a delicate and poorly understood balance between speed of bone marrow mobilization, engraftment, and turnover of EPCs at sites of vascular injury, inhibition of differentiation, and rates of apoptosis (25). Our data indicate that both aging and timing of myocardial injury act synergistically, decreasing their number in the bone marrow and their ability to migrate and form colonies.

There is no consensus about markers to identify mesenchymal stem cells in vivo (3). Although controversial as surface markers for mesenchymal stem cells, triple staining for $\mathrm{CD} 44^{+} / \mathrm{CD} 71^{+} / \mathrm{CD} 29^{+}$was significantly increased $48 \mathrm{~h}$ post-MI and attenuated 28 days post-MI in young rats. Disparate results have been reported with regard to mesenchymal stem cells and aging, with some groups finding an age-related decline in availability and function whereas others observing no change at all $(5,6,26)$. Initial studies in rats suggest that mesenchymal stem cells from aged rats depict a reduced capacity to generate chondrogenic matrix in vitro (39).

There is an increasing body of evidence supporting that alteration in the VEGFR2 and SDF-1/CXC chemokine receptor-4 (CXCR4) axis is a crucial regulator of progenitor cell function, recruitment, and homing. Van Weel et al. demonstrated that VEGF-A, SDF-1, and CXCR4 expressions were generally decreased in ischemic muscle compared with nonischemic muscle in patients with chronic ischemia, whereas they were substantially increased in patients with acute-on-chronic ischemia (35). Recently, Seeger et al. have elegantly demonstrated that $\mathrm{CXCR}^{+}$bone marrow cells exhibit an increased therapeutic potential for blood flow recovery after acute ischemia. These investigators have demonstrated that $\mathrm{CXCR} 4^{+}$bone marrow cells have higher mi- gratory capacity secondary in part to an increased release of paracrine factors (31). All these data concur with the concept that hypoxic preconditioning may be crucial to enhance cell therapy effectiveness. In this context, Tang et al. have found that hypoxic preconditioning increased CXCR4 expression in cardiosphere-derived, Lin $^{-} \mathrm{c}-\mathrm{kit}^{+}$progenitor cells and markedly augmented their in vitro cell migration and in vivo recruitment to the ischemic myocardium. These effects were largely abolished by the addition of a CXCR4 inhibitor, indicating that the benefits of hypoxic preconditioning are in fact mediated by the SDF-1/CXCR4 axis (34).

Some aspects of our study design and methodology deserve consideration. We acknowledge that there is no consensual definition of markers for the different populations of stem cells in vivo (3). In the current protocol, we chose to use the most widely accepted expression markers both for mesenchymal and endothelial progenitor cells. Also, as we did not include a non-BM-MNCtreated group, we cannot assure that BM-MNC per se led to any substantial treatment benefit on LV function, particularly in aged group. Real-time PCR analysis for the SRY gene was particularly heterogeneous in different experimental groups and in specimens from the same animals, precluding definitive conclusions and comparative analysis of late engraftment. In this regard, engraftment heterogeneity may occur in part because of the intrinsic variability of intramyocardial administration of stem cells in rodent models and differences in cell viability related to microenvironment aspects of the myocardial tissue.

In conclusion, we have demonstrated that aging and heart disease are factors that may act synergistically determining stem cells availability and function. These and other factors that might influence stem cell mobilization, homing, engraftment, and differentiation are vital when planning new strategies to treat acute and chronic ischemic heart disease with novel cell regenerative therapies.

ACKNOWLEDGMENTS: This work was supported by grants from the Conselho Nacional de Desenvolvimento Científico e Tecnológico $(\mathrm{CNPq})$ and Fundo de Incentivo a Pesquisa (FIPE-HCPA). Ana Ayala-Lugo was supported by an international exchange scholarship from CAPES/CNPq. We thank Maria Luiza Saraiva Pereira for the insightful comments and help on real-time PCR analysis.

\section{REFERENCES}

1. Assmus, B.; Schachinger, V.; Teupe, C.; Britten, M.; Lehmann, R.; Dobert, N.; Grunwald, F.; Aicher, A.; Urbich, C.; Martin, H.; Hoelzer, D.; Dimmeler, S.; Zeiher, A. M. Transplantation of progenitor cells and regeneration enhancement in acute myocardial infarction (TOPCAREAMI). Circulation 106(24):3009-3017; 2002.

2. Chambers, S. M.; Goodell, M. A. Hematopoietic stem cell aging: Wrinkles in stem cell potential. Stem Cell Rev. 3(3):201-211; 2007. 
3. da Silva Meirelles, L.; Caplan, A. I.; Nardi, N. B. In search of the in vivo identity of mesenchymal stem cells. Stem Cells 26(9):2287-2299; 2008.

4. de Macedo Braga, L. M.; Lacchini, S.; Schaan, B. D.; Rodrigues, B.; Rosa, K.; De Angelis, K.; Borges, L. F.; Irigoyen, M. C.; Nardi, N. B. In situ delivery of bone marrow cells and mesenchymal stem cells improves cardiovascular function in hypertensive rats submitted to myocardial infarction. J. Biomed. Sci. 15:365-374; 2008.

5. Fehrer, C.; Laschober, G.; Lepperdinger, G. Aging of murine mesenchymal stem cells. Ann. NY Acad. Sci. 1067: 235-242; 2006.

6. Fehrer, C.; Lepperdinger, G.; Mesenchymal stem cell aging. Exp. Gerontol. 40:926-930; 2005.

7. Fernandez-Aviles, F.; San Roman, J. A.; Garcia-Frade, J.; Fernandez, M. E.; Penarrubia, M. J.; de la Fuente, L.; Gomez-Bueno, M.; Cantalapiedra, A.; Fernandez, J.; Gutierrez, O.; Sanchez, P. L.; Hernandez, C.; Sanz, R.; Garcia-Sancho, J.; Sanchez, A. Experimental and clinical regenerative capability of human bone marrow cells after myocardial infarction. Circ. Res. 95(7):742-748; 2004.

8. Geiger, H.; Koehler, A.; Gunzer, M. Stem cells, aging, niche, adhesion and Cdc42: A model for changes in cellcell interactions and hematopoietic stem cell aging. Cell Cycle 6(8):884-887; 2007.

9. Heeschen, C.; Lehmann, R.; Honold, J.; Assmus, B.; Aicher, A.; Walter, D. H.; Martin, H.; Zeiher, A. M.; Dimmeler, S. Profoundly reduced neovascularization capacity of bone marrow mononuclear cells derived from patients with chronic ischemic heart disease. Circulation 109:1615-1622; 2004.

10. Hristov, M.; Erl, W.; Weber, P. C. Endothelial progenitor cells: Mobilization, differentiation, and homing. Arterioscler. Thromb. Vasc. Biol. 23(7):1185-1189; 2003.

11. Huang, L.; Hou, D.; Thompson, M. A.; Baysden, S. E.; Shelley, W. C.; Ingram, D. A.; March, K. L.; Yoder, M. C. Acute myocardial infarction in swine rapidly and selectively releases highly proliferative endothelial colony forming cells (ECFCs) into circulation. Cell Transplant. 16(9):887-897; 2007

12. Huwer, H.; Winning, J.; Vollmar, B.; Welter, C.; Lohbach, C.; Menger, M. D.; Schafers, H. J. Long-term survival and hemodynamic improvements after neonatal cardiomyocyte and satellite cell transplantation into healed myocardial cryoinfarcted lesions in rats. Cell Transplant. 12(7):757767; 2003.

13. Janssens, S.; Dubois, C.; Bogaert, J.; Theunissen, K.; Deroose, C.; Desmet, W.; Kalantzi, M.; Herbots, L.; Sinnaeve, P.; Dens, J.; Maertens, J.; Rademakers, F.; Dymarkowski, S.; Gheysens, O.; Van Cleemput, J.; Bormans, G.; Nuyts, J.; Belmans, A.; Mortelmans, L.; Boogaerts, M.; Van Der Werf, F. Autologous bone marrow-derived stem-cell transfer in patients with ST-segment elevation myocardial infarction: Double-blind, randomised controlled trial. Lancet 367:113-121; 2006.

14. Kissel, C. K.; Lehmann, R.; Assmus, B.; Aicher, A.; Honold, J.; Fischer-Rasokat, U.; Heeschen, C.; Spyridopoulos, I.; Dimmeler, S.; Zeiher, A. M. Selective functional exhaustion of hematopoietic progenitor cells in the bone marrow of patients with postinfarction heart failure. J. Am. Coll. Cardiol. 49(24):2341-2349; 2007.

15. Li, T. S.; Takahashi, M.; Ohshima, M.; Qin, S. L.; Kubo, M.; Muramatsu, K.; Hamano, K. Myocardial repair achieved by the intramyocardial implantation of adult cardiomyocytes in combination with bone marrow cells. Cell Transplant. 17:659-703; 2008

16. Lunde, K.; Solheim, S.; Aakhus, S.; Arnesen, H.; Abdelnoor, M.; Egeland, T.; Endresen, K.; Ilebekk, A.; Mangschau, A.; Fjeld, J. G.; Smith, H. J.; Taraldsrud, E.; Grøgaard, H. K.; Bjørnerheim, R.; Brekke, M.; Müller, C.; Hopp, E.; Ragnarsson, A.; Brinchmann, J. E.; Forfang, K. Intracoronary injection of mononuclear bone marrow cells in acute myocardial infarction. N. Engl. J. Med. 355: 1199-1209; 2006.

17. Min, J. Y.; Yang, Y.; Sullivan, M. F.; Ke, Q.; Converso, K. L.; Chen, Y.; Morgan, J. P.; Xiao, Y. F. Long-term improvement of cardiac function in rats after infarction by transplantation of embryonic stem cells. J. Thorac. Cardiovasc. Surg. 125(2):361-369; 2003.

18. Morrison, S. J.; Wandycz, A. M.; Akashi, K.; Globerson, A.; Weissman, I. L. The aging of hematopoietic stem cells. Nat. Med. 2:1011-1016; 1996.

19. Nozawa, E.; Kanashiro, R. M.; Murad, N.; Carvalho, A. C.; Cravo, S. L.; Campos, O.; Tucci, P. J.; Moises, V. A. Performance of two-dimensional Doppler echocardiography for the assessment of infarct size and left ventricular function in rats. Braz. J. Med. Biol. Res. 39:687695; 2006.

20. Orlic, D.; Kajstura, J.; Chimenti, S.; Limana, F.; Jakoniuk, I.; Anderson, S. M.; Li, B.; Pickel, J.; McKay, R.; NadalGinard, B.; Bodine, D. M.; Leri, A.; Anversa, P. Bone marrow cells regenerate infarcted myocardium. Nature 410:701-705; 2001.

21. Orlic, D.; Kajstura, J.; Chimenti, S.; Limana, F.; Jakoniuk, I.; Quaini, F.; Nadal-Ginard, B.; Bodine, D. M.; Leri, A.; Anversa, P. Mobilized bone marrow cells repair the infarcted heart, improving function and survival. Proc. Natl. Acad. Sci. USA 98(18):10344-10349; 2001.

22. Pelliccia, F.; Pasceri, V.; Meoni, G.; Pristipino, C.; Ciandrocca, C.; Li, X.; La Rocca, S.; Rosano, G.; Mercuro, G.; Ricchchi, G. Numbers of endothelial progenitor cells in peripheral blood are similar in younger and older patients with coronary artery disease. Int. J. Cardiol. 133(2):277279; 2009.

23. Pfeffer, M. A.; Pfeffer, J. M.; Fishbein, M. C.; Fletcher, P. J.; Spadaro, J.; Kloner, R. A.; Braunwald, E. Myocardial infarct size and ventricular function in rats. Circ. Res. 44:503-512; 1979.

24. Ramos, G. S.; Hare, J. M. Cardiac cell-based therapy: Cell types and mechanisms of actions. Cell Transplant. 16(9): 951-961; 2007.

25. Real, C.; Caiado, F.; Dias, S. Endothelial progenitors in vascular repair and angiogenesis: How many are needed and what to do? Cardiovasc. Hematol. Disord. Drug Targets 8(3):185-193; 2008.

26. Roobrouck, V. D.; Ulloa-Montoya, F.; Verfaillie, C. M. Self-renewal and differentiation capacity of young and aged stem cells. Exp. Cell Res. 314:1937-1944; 2008.

27. Saito, T.; Kuang, J. Q.; Lin, C. C.; Chiu, R. C. Transcoronary implantation of bone marrow stromal cells ameliorates cardiac function after myocardial infarction. J. Thorac. Cardiovasc. Surg. 126(1):114-123; 2003.

28. Schachinger, V.; Erbs, S.; Elsasser, A.; Haberbosch, W.; Hambrecht, R.; Holschermann, H.; Yu, J.; Corti, R.; Mathey, D. G.; Hamm, C. W.; Suselbeck, T.; Assmus, B.; Tonn, T.; Dimmeler, S.; Zeiher, A. M. Intracoronary bone marrow-derived progenitor cells in acute myocardial infarction. N. Engl. J. Med. 355:1210-1221; 2006. 
29. Schmidt-Lucke, C.; Rössig, L.; Fichtlscherer, S.; Vasa, M.; Britten, M.; Kämper, U.; Dimmeler, S.; Zeiher, A. Reduced number of circulating endothelial progenitor cells predicts future cardiovascular events proof of concept for the clinical importance of endogenous vascular repair. Circulation 111:2981-2987; 2005.

30. Scorsin, M.; Hagege, A.; Vilquin, J. T.; Fiszman, M.; Marotte, F.; Samuel, J. L.; Rappaport, L.; Schuwartz, K.; Menasche, P. Comparison of the effects of fetal cardiomyocyte and skeletal myoblast transplantation on postinfarction left ventricular function. J. Thorac. Cardiovasc. Surg. 119(6):1169-1175; 2000.

31. Seeger, F. H.; Rasper, T.; Koyanagi, M.; Fox, H.; Zeiher, A. M.; Dimmeler, S. CXCR4 expression determines functional activity of bone marrow-derived mononuclear cells for therapeutic neovascularization in acute ischemia. Arterioscler. Thromb. Vasc. Biol. 29(11):1802-1809; 2009

32. Silva, S. A.; Sousa, A. L.; Haddad, A. F.; Azevedo, J. C.; Soares, V. E.; Peixoto, C. M.; Soares, A. J.; Issa, A. F.; Felipe, L. R.; Branco, R. V.; Addad, J. A.; Moreira, R. C.; Tuche, F. A.; Mesquita, C. T.; Drumond, C. C.; Junior, A. O.; Rochitte, C. E.; Luz, J. H.; Rabischoffisky, A.; Nogueira, F. B.; Vieira, R. B.; Junior, H. S.; Borojevic, R.; Dohmann, H. F. Autologous bone-marrow mononuclear cell transplantation after acute myocardial infarction: Comparison of two delivery techniques. Cell Transplant. 18:343-352; 2009.

33. Soares, M. B. P.; Lima, R. S.; Rocha, L. L.; Takyia, C. M.; Pontes-de-Carvalho, L.; Campos de Carvalho, A. C.; Santos, R. R. Transplanted bone marrow cells repair heart tissue and reduce myocarditis in chronic chagasic mice. Am. J. Pathol. 164:441-447; 2004.
34. Tang, Y. L.; Zhu, W.; Cheng, L.; Zhang, J.; Sun, T.; Kishore, R.; Phillips, M. I.; Losordo, D. W.; Qin, G. Hypoxic preconditioning enhances the benefit of cardiac progenitor cell therapy for treatment of myocardial infarction by inducing CXCR4 expression. Circ. Res. 104(10):1209_ 1216; 2009.

35. van Weel, V.; Seghers, L.; de Vries, M. R.; Kuiper, E. J.; Schlingemann, R. O.; Bajema, I. M.; Lindeman, J. H.; Delis-van Diemen, P. M.; van Hinsbergh, V. W.; van Bockel, J. H.; Quax, P. H. Expression of vascular endothelial growth factor, stromal cell-derived factor-1, and CXCR4 in human limb muscle with acute and chronic ischemia. Arterioscler. Thromb. Vasc. Biol. 27(6):14261432; 2007.

36. Vasa, M.; Fichtlscherer, S.; Aicher, A.; Adler, K.; Urbich, C.; Martin, H.; Zeiher, A. M.; Dimmeler, S. Number and migratory activity of circulating endothelial progenitor cells inversely correlate with risk factors for coronary artery disease. Circ. Res. 89(1):E1-E7; 2001.

37. Werner, N.; Kosiol, S.; Schiegl, T.; Ahlers, P.; Walenta, K.; Link, A.; Bohm, M.; Nickenig, G. Circulating endothelial progenitor cells and cardiovascular outcomes. N. Engl. J. Med. 353(10):999-1007; 2005.

38. Yau, T. M.; Tomita, S.; Weisel, R. D.; Jia, Z. Q.; Tumiati, L. C.; Mickle, D. A.; Li, R. K. Beneficial effects of autologous cell transplantation on infarcted heart function: Comparison between bone marrow stromal cells and heart cells. Ann. Thorac. Surg. 75(1):169-176; 2003.

39. Zheng, H.; Martin, J. A.; Duwayri, Y.; Falcon, G.; Buckwalter, J. A. Impact of aging on rat bone-marrow derived stem cell chomdrogenesis. J. Gerontol. A. Biol. Sci. Med. Sci. 62:136-148; 2007. 